

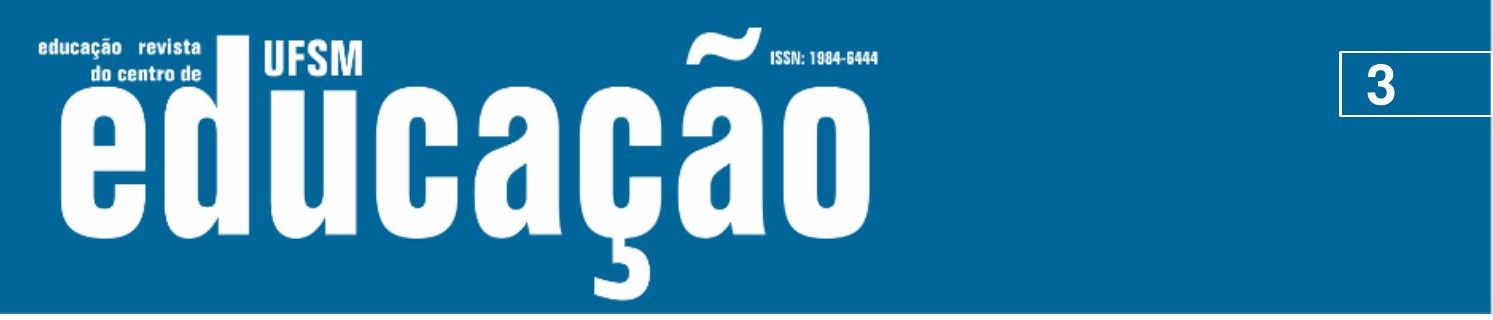

ISSN: 1984-6444 | http://dx.doi.org/10.5902/1984644461888

Bringing to the core of discussions the reality of teachers can improve the conditions for decision making regarding continuing training. Since studies in the field of teacher training affirm that for continuing training to be effective, it is necessary to provide coherence between the training practices with the demands that permeate the teaching practice, including their difficulties, problems and needs. In addition, we note the lack of solid knowledge that allows a diagnosis of the advances and difficulties of teachers in order to be able to plan more appropriate continuing training practices.

On the other hand, denying the importance of knowledge of the teaching reality in the planning of training practices, prone to fruitless continuing training practices, as confirmed by the specialized literature in the area. Therefore, we emphasize the relevance of this research work.

The investigation was carried out with 30 Arts teachers from the state elementary schools of the capital of Sergipe; they all answered a questionnaire, of which 10 Arts teachers were interviewed. It is important to note that all participants of the research signed the Informed Consent Form and furthermore the present research complies with all the requirements of the Research Ethics Committee, with the approved opinion number $3,741,282$.

This research is characterized by being of a qualitative descriptive approach, and parts of an epistemological understanding that the investigation of human phenomena is of a subjective order and therefore we have the goal of understanding how participants perceive their reality subjectively.

\section{Theoretical Referential}

The first aspect of the foundation of this research is to insert ourselves into the field of studies on teacher training. The appropriation of the boundaries of the field of research on teacher training becomes relevant because it allows us to achieve a certain homogeneity of specific definitions and favors the strengthening of the field of studies. (GARCIA, 1999) Thus, this investigation sought to insert itself and contribute, through the knowledge produced in this research, with the field of studies on teacher training. 


\section{تilloapẫ}

ISSN: 1984-6444 | http://dx.doi.org/10.5902/1984644461888

continuing training that addresses the knowledge of Arts, is due to the difficulties in teaching based on the multivalence of artistic languages. That is, those who are in the music area want to learn how to develop contents of languages different from their own, in order to meet the requirements of curricular prescriptions. Therefore, there is no denying that the co-existence of the four artistic modalities in the curriculum is an aggravating factor that permeates the training of the Arts teacher.

In the question about the results achieved after continuing training courses, the majority, $56.6 \%$ of teachers answered that there was improvement, because continued training was efficient and changed their teaching practice, and $43.4 \%$ stated that for several reasons they did not achieve effective results in their teaching practices. The absence of effective results in continuing training occurs because they do not consider the reality of the teachers, thus promoting fruitless teaching practices.

After having the questionnaires answered by 30 Arts teachers, we used 10 of these teachers to perform the second part of data production: the interview. Thus, the contents obtained through the recorded interviews were initially transcribed in their entirety. Then, an attentive and careful reading of all the material was carried out, in order to highlight the evoked contents that addressed more directly to the objectives of the research. In possession of the teachers' responses, we organized the data and defined the categories.

The analysis was organized based on 5 predefined categories:

- Difficulties and Problems;

- Achievements in teaching

- Motivations for continuing training;

- Results achieved after training;

- Themes preferences for continuing training.

We believe that all these categories are factors that in one way or another affect continuing training, because from the knowledge of difficulties and problems we will be able to know a part of the reality of the teachers and thus have adequate subsidies to plan training practices more appropriate to them. In the category referring to the achievements we will understand about what the teachers consider a good result of 


\section{T-1 usm

ISSN: 1984-6444 | http://dx.doi.org/10.5902/1984644461888

their work, in this case we believe that the goal of continuing training is to help them achieve adequate results in their teaching practice. In the third category it is about knowing the motivations that drive teachers to carry out continuing training. In the fourth category we aim to know the effects and changes achieved in the teaching practice, after the participation of training practices already carried out. And the last category, in a more direct way, we aim to elucidate the thematic preferences for continuing training that teachers list as necessary for their teacher training.

The first recurring point in the teachers' speeches that refers to difficulties and problems is the lack of recognition of the curricular component, from the students to the school institution:

"Not appreciation of the component regarding to the area of knowledge; thinking that component as a hobby". (TEACHER 6)

"The school thinks that the Arts teacher is the decorator of the school, in general they see us this way, from public to private schools." (TEACHER 1)

Based on the teachers' speeches, we realize that we still live a kind of constant search for legitimization, no longer in the past, in the formal and legal aspects, but in the cultural aspect. Common sense still sees the presence of arts in school only as a hobby, entertainment, free time to draw, etc. In the literature review we saw that this is in fact constant, and our research confirms this reality.

In addition, the devaluation of Arts teaching in schools has as a consequence the lack of commitment of students and in many other cases there is indiscipline in the classroom as a consequence, let's see:

[...] "The lack of recognition of the importance of the component on the part of the students, and this generates the disengagement of the students". (TEACHER 4)

"Unrest in the classroom", [...] "bad behavior, lack of manners, disrespect to the teacher." (TEACHER 8) 


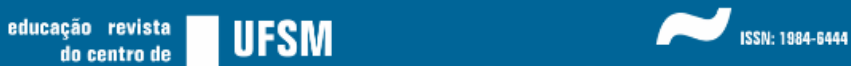

ISSN: 1984-6444 | http://dx.doi.org/10.5902/1984644461888

School indiscipline is not a phenomenon present only in Arts classes. In this specific case, the reasons that generate this type of behavior in Arts classes, according to teachers, are these that were exposed through the speech of teachers 4 and 8 .

So, which way do teachers solve the problem of indiscipline in the classroom?

[...] "I try to solve it by talking." (TEACHER 4)

[...] "I try to solve it through dialogue, but so far without success." (TEACHER 5)

[...] building a work on top of the student so that he/she recognizes the component with the value it has and through the student I get to the institution, then it is by the result of the student that the institution begins to see the component with other eyes (TEACHER 1)

We believe that the speech of teacher 1 , is close to what we commented at the beginning of the analysis, the unstable environment of Arts teaching leads the teachers to try to legitimize themselves.

The second difficulty raised in the teachers' speeches is about the lack of adequate material for classroom practices. Let's see what the teachers' speeches are:

[...] "it lacks material so that one can work with the students." (TEACHER 2)

[...] "the main problem is the question of structure and the lack of specific materials for working with certain languages." (TEACHER 3)

"Lack of specific materials for classroom practices" (TEACHER 4)

"Lack of structure, materials" (PROFESSOR 6)

"Lack of logistics of work materials in Arts laboratory". (TEACHER 7)

[...] "we do not have a specific room, a workshop, we do not have Arts material" (TEACHER 9)

The absence of adequate didactic materials is a reality not only for Arts teaching, but the teacher who is constantly seeking for self improvements may find ways out for possible solutions like this, because the lack of materials for pedagogical practices is in fact an "inhibitory factor or even, impeding the teaching action, since the teacher directly depends on the resources he/she has to be able to develop the classes with good quality." (ZAMPERETTI, et al, 2015, p. 196) 


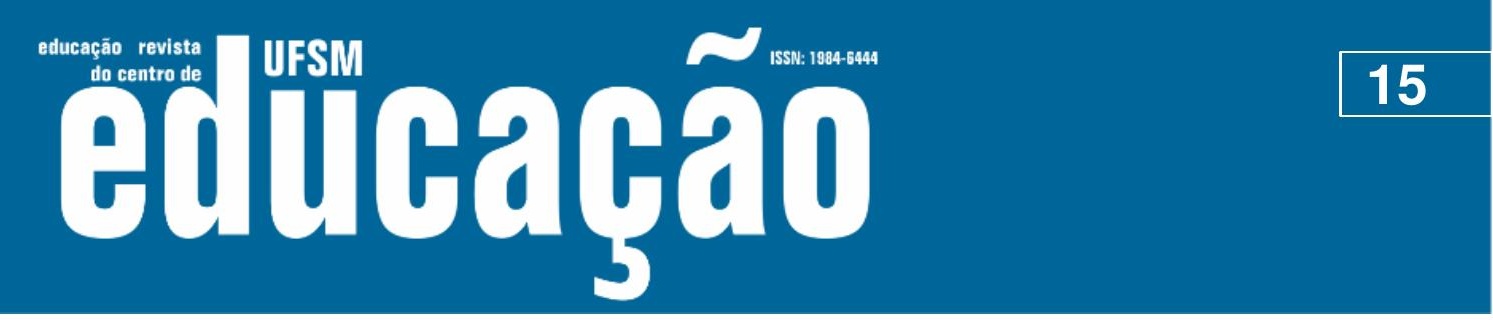

ISSN: 1984-6444 | http://dx.doi.org/10.5902/1984644461888

Another problematic factor that was raised by teachers refers to the training aspect of those who teach Art:

$[\ldots]$ teachers who are not in the area end up teaching the Arts subject, so this ends up losing a little, they don't manage to add and as a result the students come up with gaps that we try to seek the best knowledge (TEACHER 2)

[...] this question of teaching multipurpose Arts, I'm totally against it, I think it's a big backwardness, so you have content like this, interesting but shallow, you know, that's hard. (TEACHER 9)

After asking about the problematic and challenging aspects of the teacher's practices, we then turn to know the positive points, that is, the results and achievements in their teaching practice, and thus we can know what the teachers consider as a good result of their work, let's see:

[...] "the most important result is what happens in the student, not in me." (TEACHER 3)

I start building a work on top of the student so that he recognizes the component with the value it has and through the student I get to the institution, then it is by the result of the student that the institution begins to see the component with other eyes. (TEACHER 1)

From the teachers' speeches it was possible to understand the strong need to justify the Arts component regarding its importance and value, that is, to prove the importance of the Arts for the school community, it would be to achieve a good result in teaching practice. Therefore, the change of attitude of students towards the appreciation of the Arts component is considered an achievement.

In addition, we can realize in a very recurrent way the figure of the student as the objective, that is, it is in the result that the student achieves through the teacher that the results and the appropriate achievements of his teaching work are found.

Thus, we can confirm when the focus of their achievements is effectiveness in the development of their students, it really touches on the purpose of teacher training that we rely on in this study, which consists in the understanding that teacher training is not a process that is contained in the teacher, because the ultimate criterion of this course is the quality of teaching that students receive. 


\section{تilloapẫ}

ISSN: 1984-6444 | http://dx.doi.org/10.5902/1984644461888

The third point of the interviews refers to how the teacher relates to continuing training, what continuing training practices the teacher has already performed, and what were the motivations that mobilized him/her in search of training.

We can see in the teachers' speeches that motivation comes from the need to improve their teaching work. An aid to be able to overcome some difficulty in their pedagogical practices. It is also possible to perceive in the speeches certain reasons that are not of their own initiative, for example: teachers who participate in certain trainings because the majority of the other teachers are doing these trainings, because it is fashionable, not because of their real needs. There are also the cases of teachers who only participated because they were forced into doing it by the school institutions.

In this way it is possible to perceive a certain distance between teacher training and their reality, on the one hand teachers who follow educational fads, courses that promise miraculous results, and that will actually help the teachers achieve their goals in the classroom, on the other hand teachers who participate in training practices that are far from their realities.

Next, we asked the teachers about the impacts achieved after the participation of continuing training practices. The answers to this question are close to the one in the questionnaire, which also achieved similar answers. Yes, most teachers claim to have achieved some positive results after attending continuing training courses. In smaller numbers we also had teachers who said that they had not achieved positive results in their teaching practices, let's see:

No, because they are far from reality (TEACHER 2)

No, because the courses I took did not turn to practice in the classroom. They were theoretical. (TEACHER 5)

The last point of the interview is about teachers' preferences regarding what optimal continuing training should be. Aware of the challenges and difficulties experienced in the classroom and of what can encourage them to seek continuing training. We asked the teacher, what the continuing training for teachers who teach Arts in Basic Education should be. 


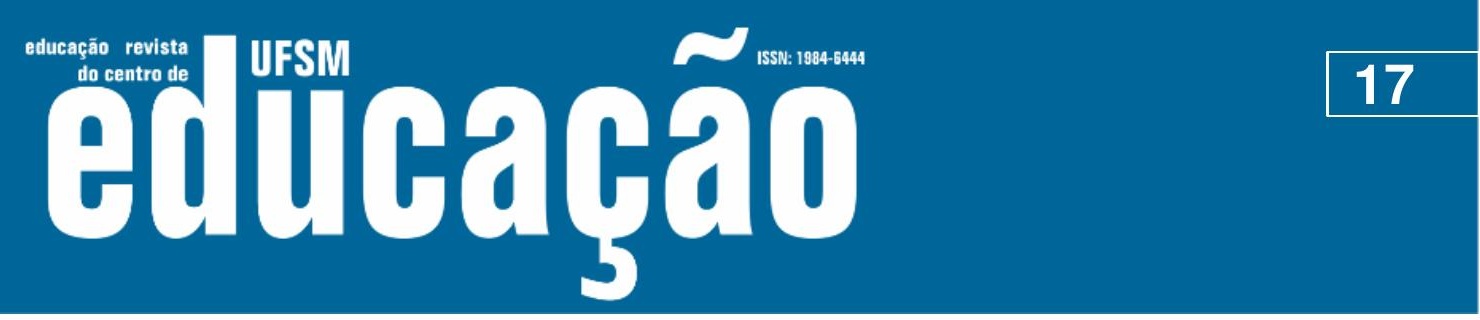

ISSN: 1984-6444 | http://dx.doi.org/10.5902/1984644461888

When analyzing the teachers' responses, it is evident that the majority of teachers believe that continuing training should help the teacher acquire knowledge regarding the artistic languages that were not addressed in their initial training.

The second aspect that was also recurrent in the teachers' speech refers to the need for continuing training courses to emphasize the practical character of teaching. They affirm that most of the continuing trainings that they participated in had a more theoretical character, and thus, when they tried to transpose this knowledge into practice, the effective realization of the new acquired knowledge was not achieved.

In order to synthesize all the information reached in the interviews, we will present below a chart that was made and organized according to the categories adopted and the most recurrent answers provided by the Arts teachers:

Chart 1 - Interview Analysis Framework

\begin{tabular}{|c|c|}
\hline \multicolumn{2}{|c|}{ CATEGORIES AND ANSWERS } \\
\hline DIFFICULTIES AND PROBLEMS & $\begin{array}{l}\text { - Lack of appreciation of the curricular component } \\
\text { - Lack of suitable material for classroom practices } \\
\text { - Gaps in training }\end{array}$ \\
\hline $\begin{array}{l}\text { PROGRESSES } \\
\text { ACHIEVEMENTS }\end{array}$ & - Student Development \\
\hline $\begin{array}{l}\text { MOTIVATIONS FOR CONTINUING } \\
\text { TRAINING }\end{array}$ & $\begin{array}{l}\text { - It was proposed by the school } \\
\text { - In order for the student to recognize the value of } \\
\text { the arts } \\
\text { - Help in deepening my teaching practice } \\
\text { - } \text { Because of the difficulties in working content } \\
\text { - } \quad \text { Finance and Enhancing the professional level } \\
\text { - Artistic Interests }\end{array}$ \\
\hline
\end{tabular}




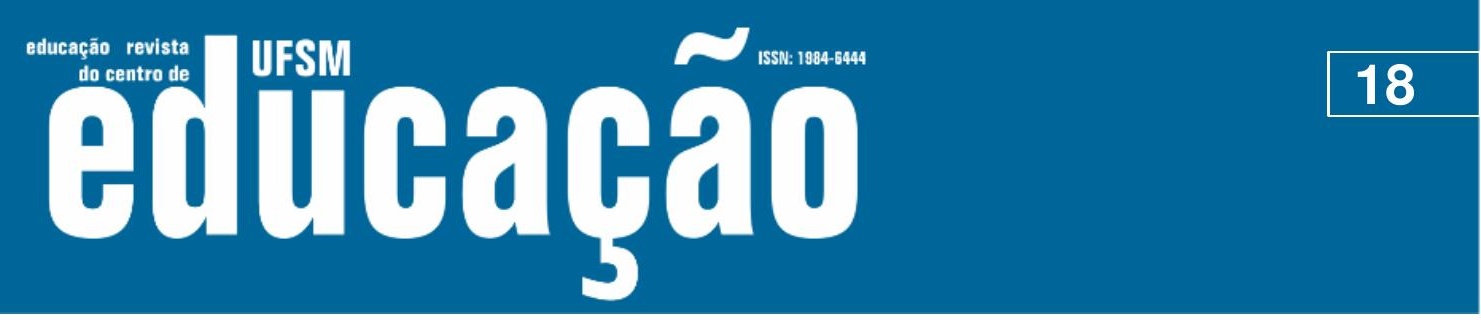

ISSN: 1984-6444 | http://dx.doi.org/10.5902/1984644461888

\begin{tabular}{|c|c|}
\hline $\begin{array}{l}\text { THE EFFECTS OF THE TRAINING } \\
\text { CARRIED OUT }\end{array}$ & $\begin{array}{l}\text { - Strengthened as a professional } \\
\text { - } \text { Organization of new ideas } \\
\text { - It did not achieve results because they were far } \\
\text { from the reality of the classroom }\end{array}$ \\
\hline $\begin{array}{l}\text { HOW SHOULD THE CONTINUING } \\
\text { TRAINING BE }\end{array}$ & $\begin{array}{l}\text { - To address the question of the multivalence of } \\
\text { artistic languages } \\
\text { - About Artistic Content } \\
\text { - About indiscipline } \\
\text { - New Teaching Methodologies } \\
\text { - About Curriculum }\end{array}$ \\
\hline
\end{tabular}

Source: Author's elaboration.

The information produced through the interviews is broader compared to the data obtained by the questionnaires. Because by the use of interviews it is possible to access dimensions that are not attainable only with the questionnaire. Through the teachers' speeches it was possible to capture pertinent information that can certainly affect their continued education.

From the description of factors such as the most recurrent difficulties of teachers, their achievements, the way in which they solve problems, their motivations to seek continuing training, the results achieved in these training courses and their opinion on how continuing training should be. All this is relevant information that should be considered in the planning of training practices.

\section{Final Considerations}

According to the state of knowledge and the results achieved in the empirical part of the research, we identified that the most recurrent difficulties are: the incoherence of curricular prescriptions, with the initial training of this teacher. The curriculum is multipurpose, but the teacher's training is specialized in only one 


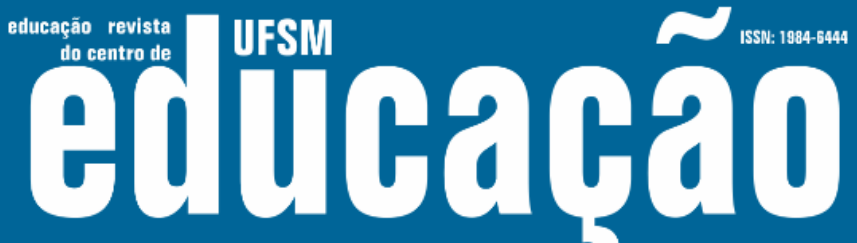

ISSN: 1984-6444 | http://dx.doi.org/10.5902/1984644461888

teachers, and that are not excessively theoretical. In addition, teachers demonstrate a great need to fill their gaps in the field of artistic languages that differ from their initial training, this shows us that the multivalence of artistic languages is still very strong, because what is required in curricular prescriptions is in dissonance with their graduation. In addition, it was possible to perceive a recurrence that continuing training approaches the thematic of specific artistic content, and its transposition into the school curriculum of Arts teaching. Teachers also positioned themselves in favor of training that help them to deal with indiscipline of students in the classroom and together with that, training courses that address in a practical and supervised dimension of the New Teaching Methodologies.

The results obtained suggest that the process of continuing training also considers aspects of the reality of the teacher, and that from this it is possible to propose training practices closer to their difficulties and not only close to the theoretical scope of teaching practices. That theory and practice can be together as two sides of the same reality for it was evidenced that many teachers still claim that training practices are excessively theoretical, and far from their reality. Therefore, it is evident that teachers understand that continuing training is essential to the teaching work, but many of these continuing trainings still do not effectively fruit in their teaching practice.

Thus, the approximation of teacher training with the demands of practice has been presented as an urgent challenge for the field of teacher training. This is why it is necessary to know the factors of the reality of the teacher, because in this way it will be possible to promote more effective training practices that consider difficulties and achievements of teachers.

Based on the theory of the teacher's professional life cycle, it was possible to recognize the relevance of the data obtained from this perspective. However, it is important to highlight caution in generalizations, since it is necessary to work with greater acuity so that more accurate data can be achieved, which is not the focus of this work

The relevance of this research is due to the dissemination of the advances and difficulties reported by teachers, in addition, this way we can contribute in the field of 


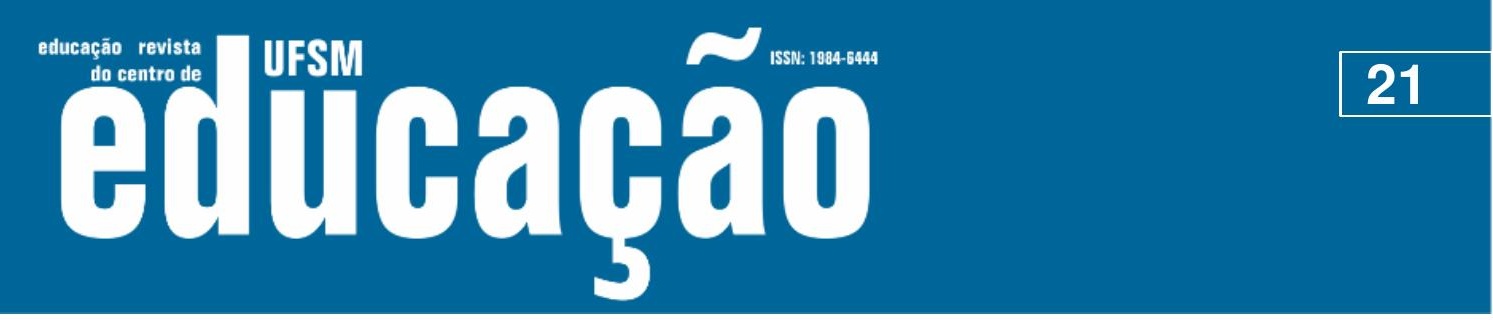

ISSN: 1984-6444 | http://dx.doi.org/10.5902/1984644461888

research of teacher training that seeks, in the teacher, knowledge necessary to promote continuing training practices more consistent with their reality.

Given the importance of the subject, it becomes necessary to raise a topic that deserves due attention. Do we want to draw attention to the question of how Arts teachers come to each other? Artist or Arts teacher? This question arose during the interviews, because we realized by means certain choices and attitudes, that many teachers still live this dilemma, of being an Arts teacher or being an artist. In fact, this is a pertinent aspect that may somehow affect the students' learning process. Thus, it would be pertinent to investigate the extent to which this dilemma affects the school.

Therefore, we hope that this research can contribute to the discussions about the knowledge of the reality of these teachers, because we believe that with this produced knowledge it will help in making decisions regarding the continuing training of the Arts teacher.

\section{References}

ARAÚJO, Gustavo Cunha de; OLIVEIRA, Sabrina Borges de; ALMEIDA, Ludimila Silva. A formação do professor de Arte em Tocantins: velhos desafios e problemas na educação brasileira. Laplage em Revista, v. 5, n. 2, p. 176-189, 2019.

BAPTAGLIN, Leila Adriana; Rosetto, Gislaine Aparecida Rodrigues a Silva; BOLZAN, Doris Pires Vargas. Professores em formação continuada: Narrativas da atividade docente de estudo e a da aprendizagem da docência. Educação Santa Maria, v.39, n.2, p.415-426, mai-ago, 2014.

BOGDAN, Robert; BIKLEN, Sari. Investigação qualitativa em educação: uma introdução à teoria e aos métodos. Portugal: Porto Editora, 1994.

CANDAU, Vera Maria Ferrão. Formação continuada de professores: Tendências atuais. In: REALI, Aline Maria de Medeiros Rodrigues; MIZUKAMI, Maria da.Graça Nicoletti (Orgs.) Formação de professores: Tendências atuais. 3 ed. São Carlos: EDUFSCar, 1996. p. 139-152.

COSTA, Roberta Mendes; BRITTO, Ariana de; WALTENBERG, Fábio. Efeitos da formação docente sobre resultados escolares do ensino médio. Estudos Econômicos (São Paulo), v. 50, n. 3, p. 369-409, 2020.

FONTERRADA, Marisa Trench de Oliveira. De tramas e fios: um ensaio sobre música e educação. Unesp, 2005. 


\section{Aillbapẫ \\ 3}

ISSN: 1984-6444 | http://dx.doi.org/10.5902/1984644461888

GARCIA, Carlos Marcelo. Formação de professores: para uma mudança educativa, trad. Isabel Narciso, Porto, Portugal: Porto Editora, 1999.

HUBERMAN, Michael. O ciclo de vida profissional dos professores. In: Vidas de professores, v. 2, p. 31-61, 2000.

LARANJEIRA, Maria Inês. et al. Referências para formação de professores. In: Bicudo, Maria Viggiani; Silva, Celestino Alves. (org.). Formação do educador e avaliação educacional: formação inicial e contínua. São Paulo: UNESP, 1999;2:174.

NOGUEIRA, Monique Andries. Educação musical no contexto da indústria cultural: alguns fundamentos para a formação do pedagogo. Educação Santa Maria, v.37, n.3, p.615-626, set./dez., 2012.

RODRIGUES, Disnah Barroso. Educação Continuada: Analisando sentidos a partir de terminologias e concepções. In: ANPED/GT02 Formação de Professores. Anais 2004.

SARDELICH, Maria Emilia. Formação inicial e permanente do professor de arte na educação básica. Cadernos de pesquisa, n. 114, p. 137-152, 2001.

SCHOPENHAUER, Arthur. A arte de escrever. Porto Alegre: L\&PM, 2007.

SILVERMAN, David. Interpretação de dados qualitativos: métodos para análise de entrevistas, textos e interações. Bookman Editora, 2009.

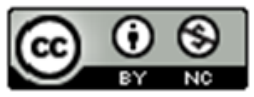

This work is licensed under a Creative Commons Attribution-NonCommercial 4.0 International (CC BY-NC 4.0)

\section{Notas}

${ }^{1}$ This study was financed in part by the Coordenação de Aperfeiçoamento de Pessoal de Nível Superior - Brasil (CAPES) - Finance Code 001 